\title{
Social-Economic Immobility: A Study of Fishermen's Struggle among Corporation Powers in the East Coast of Kalimantan, Indonesia
}

\author{
Setiadi, Agus Yuliono, Sonyaruri Satiti \\ Universitas Gadjah Mada \\ Email: setiadi_antro@ugm.ac.id
}

\begin{abstract}
A majority of fishermen in the coastal areas of Bumi Seribu Nyiur Melambai, East Kalimantan, Indonesia, are migrants from other islands of Indonesia. This paper presents results from a research of the fisherman community. Most of the fisherman came from lower-middle-class families. Both lower-and lower-middle-class fisherman have access to the development program, aids and others resources delivered by government and international corporate. This paper describes how most fisherman see and believe that Bumi Seribu Nyiur Melambai is an area of battle for many actors to upscale their economic and social mobility through accumulation of wealth and social status. Many fishermen express the ambiguity, uncertainty, and marginality of their socialeconomic status. The marginal status is caused by (i) Long Story of Unequal Social Structure; (ii) elite capture of programs and aids (iii) uncertainty and the loss of fishing area due to the presence of the company; (iv) Their technology are not able to resist the change of seasons. Data in this research are collected by qualitative and quantitative method, such as a participatory observation, in-depth interview, FGD, and survey.
\end{abstract}

Keywords: corporate, elite capture, fishermen, social-economic

\section{INTRODUCTION}

This article suggests that the operation of oil companies has limited physical, social and economic space of the fishermen. Considered as vulnerable group, fishermen community has been the target of development interventions initiated by the government and the companies. Nevertheless, many actors have competed for access to the development programs and aid to upscale their social and economic status. In the power relation contexs, local elites play an instrumental role in shaping struggles for power over processes and outcomes of participatory interventions in the fishery community in East Kalimantan, which is characterized by social hierarchy. This study is conducted among fisher community in Samboja in the vastly industrialized area of Delta Mahakam. Samboja has been notorious of its fish production in East Kalimantan since 1970 s. Around 20.000 to 30.000 tons of fish were captured in the area in 1970s (Sarwono, 1989). According to Suyatna, et.al, (2010), the province had the potential to develop its fish production due to the variety of fish species in its coastal areas. . The number of fish production in the province varies from year to year. In 2015 the province produced 154.439 tons of fish, of which 106.903 tons were marine captured production and the rest of 47.536 tons were aquaculture production. Including in the aquaculture production are pond, brackish water (tambak) and bamboo cage (keramba) 
culture fishery. In 2015, brackish water culture fishery produced 28.611 tons, which comprised of $7.713,8$ tons of giant tiger prawns, $6.076,3$ tons of milkfish and 4.821 tons of crab. In addition, pond culture fisheries produced 3.563 tons, which comprised of 970,7 tons of nile tilapia, 221,9 tons of pangasius, 1.180,9 tons of common carp and $1.189,9$ tons of catfish. The production of bamboo cage (keramba) aquaculture fishery was 33.414 tons, which comprised of $8.073,9$ tons of common carp, 8.949,3 tons of nile tilapia, 3.803,6 tons of pangasius, $4.142,2$ tons of snakehead murrel and 8.445,6 tons of giant snakehead. In the same year, East Kalimantan also produced $88.445,2$ tons of seaweed, soaring from the merely $8.445,2$ tons in 2014 . The number of production was nevertheless lower than that in 2013, which reached 249.411,7 tons (Antara, April 2016).

The fishermen of Samboja are the Bugis, Banjarese, Butonese, Javanese and Sundanese migrants. As migrants, they have little awareness on locality. In addition, their social and economic status is uncertain and ambiguous. This study investigates why vertical social and economic mobility through wealth and social status accumulation do not happen among the fishermen. Why does their social and economic mobility remain ambiguous? This study reveal that the stagnant social mobility is caused by (i) unfair social structure; (ii) elite capture to aids and development program; (iii) narrowed catching area due to companies' operational demand; (iv) technology that is not able to respond to change of season. The idea of developmentalism is prominent in Samboja. It aims to improve the area through massive industrialization, which changes not only physical space but also the pattern of social and economic structure in the area. As Pelusso (2008) mentioned, the spatial change at a local scale has made ones get a better sense of both process and unintended consequences. Moreover, the developmental approach puts an emphasis on the role of elites, state capture and broader transformation of the society (Maniokas, K. 2014).

To revise the developmental approach, the government implements community driven development projects that aim to increase community's control over the development process. Unfortunately, participatory approach is also vulnerable of being dominated by the elites. The process by which the elites dominate and corrupt community-level planning and governance is called elite capture (Dasgupta dan Beard, 2007). Theoretically formulated, where there is "serious power imbalances... The poor are heavily dependent on vertical links with local elites. (Therefore) it is difficult to form the horizontal associations necessary for organizing collective action for the common good" (Das Gupta, et.al., 2004: 28). When collective action is co-opted by the interests of elites, it is likely that the elites will take benefit from it (Bardhan and Mookherjee, 2000). Moreover, when the sociocultural context of social relation is permeated by the values of harmony, conflict diminishing and the lack of check and balance, elite capture is likely to happen.

This study focuses on fishermen community in two kelurahan in Samboja, namely Sanipah and Handil Baru. Data were collected through survey, observation, in-depth interview and Focus Group Discussion (FGD). The survey was conducted in 16 April to 13 May 2015, involving 250 family respondents who were picked by listing fisherman families in the villages. As the main focus is fisherman family, $90 \%$ of the data are about fishermen family. The total number of respondents is 1.145 people from 108 families in Sanipah (282 men and 242 women) and 142 families in Handil Baru (310 men and 311 women). The fishermen respondents can be categorized as (i) those working in marine capture fishery, namely fishermen using gill net, purse seine, troll, long line and bamboo fish trap (ii) those working in aquaculture fishery, such as pond and brackish water fishermen as well as seaweed farmers and (iii) those working in fishery products processing such as fish drying and salting.

In doing observation, the researchers identified and documented fishermen's activities and how the community communicated with stakeholders. There were several observation areas, among which were fishermen settlements around the river delta (Handil Baru and Sanipah delta) and near pipe route (Sei Tanggi and Sei Mantri), a kiosk where people and youngsters often gathered, community activities such as collective prayer, government offices, Sigagu market area, weekly market both in Sanipah and Handil Baru, brackish water culture 
area that raised fish and farmed seaweed as well as places where fishermen placed their purse seine with a bamboo hut above it (belat).

Among key informants in the fishermen community were the chief and members of fishermen association, fish wholesaler and retailers as well as Punggawa (the capital owner in the patron-client structure of fishermen community). Asides from them, the informants included community figures, government officers, youth figures, community organization officers and other community members. Focused Group Discussion (FGD) was conducted 20 times in two villages, covering various themes and involving fishermen, fishermen association's officers, fisherwomen, village government officers, stakeholders in subdistrict level, community figures, youth figures and community association (RT) officers. The study employed triangulation analysis to reach conclusion and analyzed stakeholder network using statistic program.

Stakeholder mapping helps researchers to identify issues deliberated among key actors in the community, the actors' interest, the strength of each actor in influencing decision making process, their different perceptions to the existing issues, interaction among actors and actors' resources (both capital and social resources). The stakeholder mapping is conducted through the following steps. First, identifying the community's key actors through in-depth questions and focused group discussion (FGD). Second, preparing tables and graphic that illustrate information on actors' name, their alliance and network, issues in which they are involved, their interest, their capital and political support as well as their behavior. Stakeholders mapping approach that is based on stakeholders classes (Mitchell, et.al., 1997), facilitates the identification of power, legitimacy and urgency under the interest of the elites.

\section{DISCUSSION}

\section{Long story of unequal social structure}

"Our plate of rice is in the ocean", H. Said, a Sanipah fisherman.

This study was conducted in Samboja Subdistrict, Kutai Kartanegara District. With the size of $1045,90 \mathrm{~km}^{2}$, Samboja is situated in $116^{\circ} 50^{\prime} \mathrm{E}$ - $117^{\circ} 14^{\prime} \mathrm{E}$ and $0^{\circ} 52^{\prime} \mathrm{S}-1^{\circ} 08^{\prime} \mathrm{S}$ in the hemisphere. The capital of the sub-district is Samboja Kuala, located 20 meters above the sea. Samboja is now divided into 21 villages and kelurahan (urban community) and 239 sub-village associations (RT). With $4,45 \%$ population growth per year, in 2010 Samboja's population numbered 58 171. The rate of population density was 56 people/km2 in 2012 (BPS, 2013).

The beauty of Sanipah and Handil Baru coast, which was notorious for "a thousand swaying coconut trees" and its abundant sea products (so abundant that people said, "fish and shrimps were many like the heaviness of rain"), is still clear in people's memory. Most of fishermen in Handil Baru and Sanipah came from Sulawesi. Migration began in 1960-1970 when fishermen enjoyed the most success that was marked by their Haji pilgrimage and several trips home to Sulawesi. The success story had attracted the fishermen's relatives to work overseas (informans says).

Fisherman does not only refer to a profession but also to a complex social relation. Fishermen largely depend on a capital owner, which is commonly called punggawa. Punggawa provides fishermen with loan to fund their fishing activities, gives them access to market by buying their catch and maintains social relations between them. Punggawa usually maintains the fishermen's dependency on capital, while the fishermen express their gratitude to punggawa by selling their catch only to him. The punggawa-subordinate relation makes fishermen unable to set the price of their catch on their own. It is the punggawa who has been playing significant roles in the fishermen's lives. Competition to have more subordinates occurs among punggawas. Some persuade fishermen by giving them loan, some seize fishermen that already become other punggawa's subordinates to be theirs. Punggawa has the power to set the catch price, usually lower than the price set by wholesaler, retailers and buyers. Moreover, the role of punggawa can be inherited by their relatives.

Qualitative data revealed that before 1990, many residents of Handil Baru and Sanipah had already worked as fishermen other than the Bugis. In 1982, when "the fire ate the soil", referring to long drought and fire in coconut plantation, many 
Banjarese left their job in the plantation and went to sea to catch fish. As most of them only haved their manpower instead of money, boat and other fishing tools, they heavily depended on punggawa.

Now, fishermen has less space both in socialeconomic and physical sense after the establishment of oil, gas and coal companies. Responding to this situation, some fishermen decide to stay in their former place, some move to other place (menandang) and some change profession to work in the land (mendarat). The number of people working as fishermen does decrease. It is common that in one family, there are more than one people working as fishermen.

Moreover, fishermen also experience other pressure. The issuance of Ministry Decree No.2 Year 2015 has been preventing fishermen to use trawls, bottom trawls, midwater trawls, seine nets and boat seine net due to ecological reasons (news. kutaikartanegarakab.go.id, 2016). Instead of going to the sea, some fishermen attempt to work in brackish water fishery business, which provides more opportunity of diversification. Brackish water culture does not only cultivate shrimps and fish, but also seaweed (www.antaranews.com, 23 April 2015). Fishermen, however, remain in the difficult position. Their complaint on the catch decrease to the government is not sufficiently responded. Fishermen believe that many policies are issued not for their best interest but for the oil and gas companies'. The establishment of pipes for gas has made the catching area narrower because fishermen are not allowed to fish in the area less than 3 miles from the pipes. As there are several gas and oil wells in Delta Mahakam, the fishing area is limited. Abrasion also happened massively in several places of Samboja coast due to reclamation (www.1news.id/2015).

Actually catch decrease happens in the east coast of Kalimantan. Yusuf, a fisherman living in Lango, said that he and his three colleagues went fishing with a small boat and only caught one small bucket of fish. "We only caught this much while we had already spent 15 liters of kerosene," Yusuf said, referring to the insignificant result compared to the expense (www.mongabay.co.id/2013/04/24). Considering the vast growing industry in the area, it is likely that marine environment degradation has happened, which may affect the number of fish catch.

Samboja fishermen also have inadequate access to kerosene. As there is a rule that prohibits ones buying kerosene using container in gas station, fishermen buy kerosene in the sea illegally. They have demanded the government to allow gas station selling kerosene in containers and to build a gas station near the port for the fishermen. The attempt, however, has failed.

The fishermen adapt to environmental change by changing their fishing tools and doing circular migration. A fisherman may change their fishing area and set purse seine under a bamboo hut called belat, which is commonly constructed by the fishermen in Gresik, East Java. Sanipah community expects the government to dredge the river delta that has become shallow. This is to prevent sea water flowing to the river and to enable the fishermen fishing while the tide is low (www. mongabay.co.id/2013/04/24).

Among the surveyed households in Sanipah, $46,3 \%$ of them are fishermen that use belat as fishing tools, while $29,9 \%$ use gill net (renge). As many as $1,5 \%$ surveyed households are fishermen using long net (merawai) and 4,4\% using fish trap (rakang), $17,9 \%$ troll. In Handil Baru, $86,7 \%$ of the surveyed households are fishermen using gill-net (renge), 4,2\% using fish trap (rakang) and 1,7\% troll. Thus, most of the fishermen are those using belat and renge as fishing tools (PSKK Survey, 2015).

The change of land usage in Handil Baru and Sanipah reflects the economic change in the area. In the past, the coast line of Sanipah was the settlement of fishermen until Total, an international oil and gas company, operated in the area. Many shops, hotels, restaurant, houses for rent and other service business place are now built in the coastal area, leaving only a small spot near Handil Baru as fishermen settlement. This situation is different from Handil Baru, where Chevron Oil and Gas Company operate. The operation area of Chevron is not as extensive as Total. Figure 2 provides an overview of spatial change since the operation of oil and gas companies in the area. 


\section{Uncertainty and the Loss of Fishing Area due to the Presence of Oil company}

In the past, Sanipah was known as the area of bagan (net trap with bamboo hut above it) fishing. Sanipah coast has now become the operational area of Total, since 1970, much earlier than Chevron that has operated in Handil Baru since 2004. Total built their own port in Sanipah. Land usage map shows that the size of coastal or mangrove area in Handil baru is much larger than Sanipah. There are two ports built for fishermen in Handil Baru, namely Sei Raden and Handil Muara, while there is only one fishermen port left in Sanipah, namely Sanipah Muara. The size of coastal area that is accessible to fishermen affects the number of fishermen in the area. The number of fishermen in Sanipah is less than half of that of Handil Baru. Based on the survey conducted by PSKK UGM in 2015, the number of fishermen in Sanipah was 67, while in Handil Baru 120.

Ecological change began in 1990. The catch has since decreased both in quality and quantity. The oil companies built their infrastructure such as harbor by dredging the coast and installing pipes both in the water and land. The impacts of the infrastructure building are water pollution, cloudy water, belat and net destruction, narrowing fishing area, the increase of fishing cost and uncertainty of catch. The dredging of the company's port in Sanipah once every year has transported mud to the fishing area, which tear fishermen's net and reduce catch. The mud effect may happen for months because the mud spread to the sea and coast as well.

Oil installation built in the water also changes the fishermen's fishing route and area. Fishermen move further to the sea, making them spending more money for fuel while their catch decreases. Some of the fishermen shifted to brackish water culture but lasted only until 2000. The establishment of brackish water pond had, however, deteriorated mangrove forest.

Following the reduction of physical and economic space, and thus reduction of fishermen's access to resources, there is a high demand for the government and oil companies to address the issue. The government has introduced several development programs such as trainings (fiber boat making, fishing equipment usage, net making, sea product processing), environmental improvement (ulin wood installation in the coast to prevent abrasion, port establishment, irrigation revitalization, canal and river management in the coastal area) and distributing aid (fishing tools such as gill net and cool boxes, saving and loan fund, port establishment, fishing boat donation). Three oil companies, namely Total, Chevron and ENI (a company that will operate in Handil Baru in the near future), have initiated a CSR programs that aimed to distribute fishing tools (trammel net and gill net (rengge)), give compensation before dredging the coast and distribute mangrove buds.

Figure 1

Spatial change due to the operation of oil company

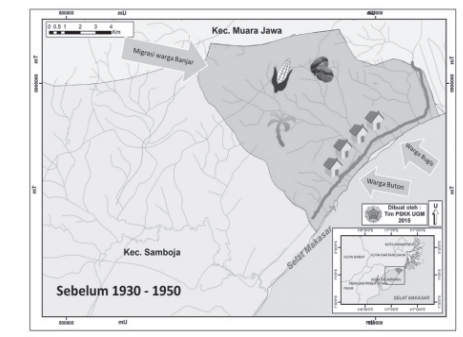

Source: PSKK UGM Survey 2015
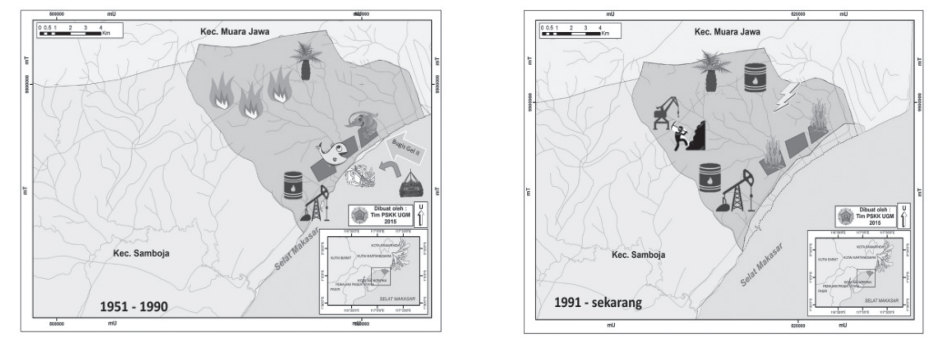


\section{Technologies not Being Able to Resist the Change of Seasons}

In June to October the sea is rough, the tide is high and the wind blows heavily. It is the south season, where most fishermen will not be able to fish. They call such a time as scarcity period (paceklik). In the past, those months were even called widow months because many fishermen died in the sea during the period, making their wife widow. The fishermen whose fishing tools are use fish trap (rakan), gill-net (renge), and purse seine cannot go fishing. To survive, they work clearing field harvesting and peeling coconuts, digging ditches and becoming construction worker.

Most of the fishermen temporarily move to other place that is not affected by the wind and tide of south season to fish. This practice is called menandang in local language. The fishermen of Sanipah and Handil Baru, particularly those who have boat, move to Muara Badak and stay for several days there to fish. Before menandang, they go to the shops to take food and fuel supplies and pay them later after returning from Muara Badak.

When the fishermen move to Muara Badak, they are likely to be bonded with new punggawa. Some punggawa from Handil Baru even follow their fishermen to Muara Badak. They provide fishermen with house to stay and food. Every punggawa in Muara Badak usually has 10-20 fishermen subordinates. In addition to south season, the fishermen also recognize north season (November to May), where the sea is calmer and safer to fish. The north season is also called fish months.

\section{Fishermen's Dynamics in Government and CSR Program}

The first fishermen associations in Handil Baru, Harapan Baru and Harapan Jaya, was established in 2007. The government and oil companies require fishermen to register their association to Fisheries and Marine Office (DKP) and kelurahan government in order to access aid and empowerment program. The number of fishermen association increases and they receive more aid through empowerment programs initiated by the government and oil companies through their Corporate Social Responsibility (CSR) program.
The growing number of fishermen association has actually weakened the power of punggawa as DKP and oil companies only recognize the associations. Many fishermen, who were tied to punggawa in the past, now become the members of association.

Despite of its eased access to government aid and CSR program, fishermen associations create insignificant impact to their fishermen members' welfare. The chief of fishermen association acts like punggawa and even two punggawas become the chief of fisherman associations. Although the chief does not play role in setting the fish price, he does have the power to determine who can become the member of the association and who cannot. Some associations are even comprised of family members and relatives, which makes associations a place for certain family to accumulate access. The chief also hasve access to information on empowerment program and aid distributed by the government and companies. There are many fishermen who cannot join the association because of various reasons, among which are that they are not the family of the chief, they belong to different community association (RT), they do not trust the chief and they have to pay contribution that is too costly for them.

The Ministry of Marine and Fisheries helped 4 fisherman associations in Handil Baru and 2 associations in Sanipah to manage saving and loan program in 2014. Each association received 100 million rupiah. Most of the loan was unpaid and the reporting was poor. In addition, many fishermen perceived that the money was not a loan but a grant. The program thus did not solve fishermen's financial problem. In Focus Group Discussion (FGD) that involved 15 fishermen in Handil Baru and held on 15 May 2015, it was revealed that fishermen now preferred to borrow from fishing equipment or food supply shop. Fishermen, thus, cannot release themselves from debt. Moreover, the empowerment programs for fishermen only provides short-term benefit. Aided fishing equipments such as gill-nets do not last long and neither does a modern boat in Handil Muara, which is now broken and unused. In addition, fishing and sailing technology used by fishermen are inadequate in responding to ecological and seasonal change. As mentioned previously, fishermen use traditional fishing 
equipments such as gill net, belat, fish-traps and long lines. The compensations given to fisherman by oil companies have less significant effect to alleviate the impacts of the company's operation. Fishermen become the target group of several empowerment programs initiated by the government and oil companies. The problem following the empowerment program is elite's competition to get access to the program.

Aside from demanding the implementation of empowerment program to aid them (which, unfortunately, brings less significant impacts to their welfare), fishermen also demand the company to provide jobs for their children. The number of fishermen in the area is likely to decrease in the future because the old ones will retire while the young ones are reluctant to take their place. Most of the youngsters prefer to work in the company than fishing for the following reasons (1) working in the company is considered to provide more security than fishing or farming because of the monthly pay, (2) company's work is considered less tough than fishing as workers get two days off in a week, (3) a young man working in the company has more prestige than one who works in the sea or farm, (4) it is believed that parents now preferred a son in law who works in the company, (5) parents, particularly fishermen, do not want their children to have similar profession with theirs because they want the next generation to have better life.

Working in the oil company is seen as a solution to decreased welfare due to catch decrease. Unfortunately, the companies have limited vacant posts and they require certain level of education and skill, of which most fishermen children cannot meet. Worker recruitment by oil companies always becomes a heated issue due to tough competition.

\section{Elite Capture of Programs and Assistance}

Kusumawati (2016) addresses the question on how to capture the elites for empowerment project implementation. Elite capture is an attitude or action of a group of people to influence policy and decision making process for the fulfillment of their interest either in material or non-material form. Since the introduction of participatory approach in development that "putting the last first"(Chambers, 1983), the model of learning with the poor has resulted on new domination model in the community, namely the emergence of learning elites (Wilson, 2006). Acting as development brokers, the elites place themselves as the community's representation and connect the target community with external parties, (Platteau dan Gaspart, 2003: 3). In Kenya, cases show that elite capture seriously undermines the outcome of development projects (Rigon, A., 2014). Platteau, J.-P.a , Somville, V.b, Wahhaj, Z.c (2014) mentions that elite capture happens because of information distortion, which occurs in the situation where (i) communities are heterogeneous and dominated by the local elite, (ii) the elite strategically proposes a project to the donor, knowing that the latter has imperfect knowledge of the needs of the target population.

This specific study considers the existence of power networks of local elites as a fundamental importance of social fact and the starting point for the study of patronage in the governance of the coastal area of East Kalimantan. It also analyzes the multiple-scale networks of local power holders (punggawa), the collaboration and friction between the political-economic interests and historical values of local actors and the scientific motivations of international environmental organizations. This study describes how collaboration and friction between members of the elite challenge models that categorically exclude or co-opt local elites in foreign projects. In-depth ethnographic study of these networks shows their resilience through flows of knowledge and power in a highly volatile coastal environment. Results indicate the need for inclusion in decision making of local entrepreneurs, and - indirectly - their dependents in decentralized coastal governance.

Warren C. (2016), through a set of Indonesian case studies that examine practices of local leaders and elites, overviews theoretical controversies on leadership, patronage and elite capture that challenges the assumptions across a wide range of current policy literature. The studies also seek to account in structural terms for appropriation both by "elite capture" and of "captured elites" as well as to explore the structural factors and co-governance practices most likely to promote effective participation of the full spectrum of local interests in pursuit of better local natural resource governance. 
Lucas, A. (2016) examines leadership, elite capture and corruption in two villages in Sumatra. His paper compares implementation and outcomes of several conservation and development projects in the context of democratization and decentralization reforms introduced in Indonesia since 1998. Focusing on the activities of local elites, particularly village officials, who use their positions to monopolize planning and management of projects that were explicitly intended to incorporate participatory and accountability features, the study finds that while elites' use of authority and influence to benefit personally from their roles clearly reflects elite capture, there are nonetheless members of elite groups in these case studies who use their control of projects to broad community benefit. In both villages there is considerable friction between villagers and elites as well as among members of the local elite themselves over control of local resources. Differences in the structure of these cross-cutting internal relationships and of ties between local authorities and outside government and nongovernment agents largely explain the differences in degree of elite capture and its outcomes in the two cases.

In 2014, The Department of Marine and Fisheries of Kutai Kartanegara District held trainings for fishermen to improve the fishermen's knowledge and skills in fisheries, particularly aquaculture related fisheries. The next training program, fish farming technique, targeted 100 hundred fishermen in 18 sub-districts. Other programs include boat repairing program, which targets 1000 fishermen in 18 sub-districts (Rakhmad and Ali, 2015:18).

With the presence of oil companies in their area, fishermen community has to deal with other entities in the coastal areas. Contestation happens in various level within and among (1) fishermen associations, communities, non-government organizations, political party's success team; (2) companies, particularly smaller companies that bid for government and bigger company's projects; (3) local government bodies (Village Association (RT), Community Empowerment Body (LPM), Village Governance Body (LPD), kelurahan government and sub-district government). Both formal and informal organizations play multiple roles and set multiple goals as well, namely struggle for the organization's interests, access to government and company's projects and the role of man power supplier. Such strategic positions with multiple roles are usually competed for.

The issue of locals vs migrants often emerges during company worker recruitment. Community organizations and non-government organizations demand the company to prioritize the recruitment for the locals. In fact, access to employment is often controlled by a group of family members and relatives. Some of the local residents have to spare some of their salary as compensation to their group or non-government organizations for helping them getting a job in the company. The role of man power supplier played by the elites has become a boomerang for the locals because it limits their own space.

Local groups and organizations such as Kalimantan Native Youth Movement (GEPAK), State Defend Command (Kobra), East Kalimantan Customary Youth Movement (LPADKT), Dayak Customary Heritage Guarding Command (KOPPAD), Pemuda Pancasila (PP) and river (Sei) based youth organizations also participate in the contestation with their own interests. In 2008, Chevron initiated Local Business Development (LBD) program for the community around the company in Handil Baru and Sanipah. Since 2010, small companies have emerged in the area.

In some cases where competition to gain access to oil company's projects happens, the issue of local identity emerges or being deliberately used in certain situations. In the area that is closer to the location where the company operates, contestation among elites escalates. The categorization of area around the company from most to least impacted based on ring pattern, has affected the scale of empowerment program, aid and man power demand in different areas. Fishermen are also involved in this contestation among local elites and even within their own group, which is controlled by the chief of association.

The emergence of new elites (both in group and individually) that only work for their own interest as well as of non-government organizations, youth organizations and customary law based organizations is the excess of economic dynamics that depends heavily to the government and oil 
companies. The competition to gain access to government and oil company projects reflects the phenomenon of elite capture.

This study finds that local elites do not represent the interests of all community members. Local organizations formed by the community and oil companies that are originally aimed to strengthen the community's economic potentials have otherwise reflected resource distribution pattern among the elites. Power is thus polarized and different groups compete for the fulfillment of their interests. In one kelurahan, the power holders are polarized into the most powerful (the elites) and the less powerful (non-elites). In addition, no community figures can be counted on to mediate or settle the conflict. Extreme polarization has created wider gap and provided less space for integration.

Figure 2

Stakeholder map in Handil Baru and Sanipah
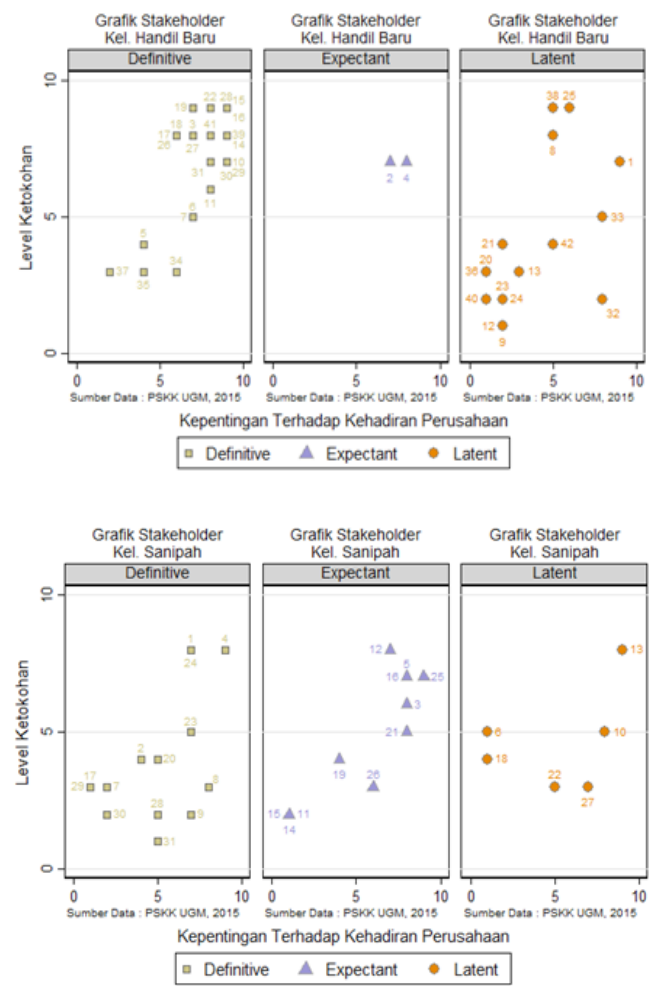

Source: PSKK UGM, Survey 2015

Based on their interests to the companies, the elites can be categorized as those who have high interests (most of them are definitive stakeholders) and those who have no interests at all (most of them are latent stakeholders). The most powerful elites are commonly definitive stakeholders. They use the position to gain opportunity to control aid program, such as monopolizing water and sanitation program for their own family and relatives. Most of the elites with less power are latent stakeholders, who have not yet been able to use their potential due to their marginal position in power relation.

Familial relationship is the basis of power in Handil Baru. Community members, including the youth, often criticize the situation of elites competition, but the criticism is conducted behind the elite's back so that the latter do not recognize that. One of the youth, who is the member of Youth Organization (Karang Taruna) mentioned:

"We do not want to get involved in those bickering because they are our relatives. If we have debate with intelligent person, we will be intelligent as well, but debating with thug will make us thug, too. There are many aid but we do not know where it has gone...Every organization (including LPM) can propose a project to Kelurahan government with the budget less than 200 million. Companies can give them too. Many organization officers used their organization jacket to have access to projects, " (interview statement, 27 April 2015).

Check and balance function does not work because some elites are relatives. Social harmony is maintained with the expense of critical attitude and apathy. In Sanipah, the power map is incongruent; the elites who have most interests to companies do not always take active roles. Thus, the elites who structurally have power in the community are not automatically definitive stakeholders.

This study also finds that government and non-government organizations avoid opened conflict by distributing programs and projects among themselves. Actually, some government and company initiated projects that are aimed to be spaces for integration become arenas of competition. Community self-help programs do not exist anymore because most programs, such as water channel outlet building, canal management and community collective work, are now funded by the government or companies. Community groups 
and actors compete for access to natural resources the most, but now empowerment programs and the status as man power supplier are also valuable resources to be competed for. The vulnerable fisherman community is often caught in the middle of elite competition.

The categorization of area around the company from most to least impacted one has set the coastal area as the most impacted one. The fishermen are thus the target of empowerment program and the coast has been the arena of elite contestation, which does not only involve the fisherman but also other parties. This shows that the community tend to take direct benefit from the company by optimizing their material resources and using their position (social capital). When the operation area of the company expands, elites capture follows and stakeholder map changes as it is possible that new elites emerge and old ones loose their power.

Government and oil company initiated empowerment programs have triggered fishermen to establish fisherman association, which ideally serves as new social network that replaces punggawa-subordinate relation. In fact, the association is merely an administration requirement to access the empowerment and aid program. Elite capture has made fishermen association weak and the empowerment programs have placed the fishermen as dependant to external help. The existing empowerment programs have not yet succeeded to promote the establishment of fishermen learning community that is self-reliant, participatory and supportive to environment restoration.

\section{CONCLUSION}

The operation of oil companies has limited the physical, social and economic space of the fishermen in Handil Baru and Sanipah. The fishermen are powerless in their relation with punggawa, while fisherman association has been marginalized in the midst of elite capture of empowerment program. This study reveals that instead of competing for access to physical spaces and company's operational benefit, the elites fight for the access to empowerment programs funded by oil and gas companies. Problems happen when the programs do not focus to community welfare and environmental sustainability. As a result, fishermen will gradually leave the coastal areas.

The fact that the community members are migrants contributes to the weak socio-cultural bond to local issues that they tend to put their individual and group interests first. Competing for access to empowerment program, aid and the status as man power supplier, the elites take the strategy of defense mechanism by narrowing down and reducing the identity of social and community space based on different interests. This is the pattern of elite capture that is prominent in this case.

Stakeholder map configuration is fluid and changes frequently due to elite's contestation. Social relations are biased when company interests involve, which results on community and social space reduction. Ones can perceive it as horizontal conflict from the outside, while from the inside groups actually negotiate to distribute access to aid and empowerment programs among themselves. At certain period of time (the length of public officer's office period or during election process) or when new programs are implemented, new actors may emerge and another may resign. There is no dominant elite in the center as the power is fragmented to many elites.

In the implementation of development program, it is important to evaluate the performance of local elites. Community empowerment and CSR programs actually contribute to the elites' wealth accumulation and support local elite's status quo. The elites have broader network and influence than other community members, including fishermen. The empowerment programs have widened social gap in the coastal community and raised latent conflict that will explode once the empowerment or CSR programs diminish.

\section{REFERENCES}

ADB. (2011). Regional: Developing Sustainable Alternative Livelihoods in Coastal Fishing Communities in the Coral Triangle: Indonesia and Philippines. https://www.adb.org/ projects/44129-012/main.

Ambarini. Nur Sulistyo Budi dan Septaria. Ema (2014). Impact of Coal Waste as Fishermen of Women Business Micro, Small and Medium Enterprises in the Coastal Fisheries Sector. South East Asia Journal of Contemporary 
Business, Economics and Law, Vol. 5, Issue 4 (Dec.) ISSN 2289-1560.

Baran, E. Hambrey, J. (1999). Mangrove conservation and coastal management in Southeast Asia: What impact on fishery resources? (Review). Marine Pollution Bulletin. Volume 37, Issue 8-12, December. Pages 431-440.

Bardhan, P. and D. Mookherjee (2000). "Capture and Governance at Local and National Levels". American Economic Review 90(2): 135-9.

Bosma, Roel H.; Roothaert, Ralph L.; Ibrahim (2001). Economic and social benefits of new forage technologies in East Kalimantan, Indonesia. Centro Internacional de Agricultura Tropical (CIAT), Los Baños, Laguna, PH. 51 p. (CIAT working document no. 190).

BPS, 2013. Kutai kartanegara dalam Angka. Badan Pusat Statistik Kabupaten Kutai kartanegara.

Chambers, R. (1983). Rural Development: Putting the Last First. London: Longman.

Coastal Resources Center dan Save the Balikpapan Bay Foundation. 2004. Coastal Community Development in East Kalimantan, Indonesia Final Report (December 2002 - December 2003) Submitted to: UNOCAL Foundation (Grant Agreement Number 2002-JGP).

Coe, C.A. (2016). The allocation of householdbased forest protection contracts in Tam Dao National Park, Vietnam: Elite capture as a bureaucratic impulse against community capture.Journal of Sustainable Forestry, 35 (2), pp. 89-118. https://www.scopus.com/inward/ record.uri?eid=2-s2.0-84958929128\&partne $\mathrm{rID}=40 \& \mathrm{md} 5=6477 \mathrm{f} 757 \mathrm{~b} 6 \mathrm{decbff} 7 \mathrm{e} 60 \mathrm{ea} 001$ 92 beacc

Das Gupta, M., H. Grandvoinnet and M. Romani (2004). "State-Community Synergies in Community-driven Development". Journal of Development Studies 40(3): 27-58.

Dasgupta, A. and V.A. Beard (2007). “Community Driven Development, Collective Action and Elite Capture in Indonesia". Development and Change. 38(2): 229-49.

Dasgupta, Aniruddha dan Beard, Victoria A. (2007). Community Driven Development, Collective Action and Elite Capture in Indonesia. Development and Change. 38(2): 229-249. (2012). Managing small marine operations in the Mahakam Delta to increase compliance and minimize risks (Conference Paper) Society of Petroleum Engineers - SPE/APPEA Int. Conference on Health, Safety and Environment in Oil and Gas Exploration and Production 2012: Protecting People and the Environment - Evolving Challenges. Volume 1, 2012, Pages 342-350.

Hugo. Graeme J. (1982). Circular Migration in IndonesiaAuthor(s): Population and Development Review, Vol. 8, No. 1 (Mar), pp. 59-83Published by: Population CouncilStable URL: http://www.jstor.org/stable/1972690 .Accessed: 16/03/2013 02:26Your

Ini inovasi budidaya rumput laut di tambak ikan, udang. Kamis, 23 April 2015 02:20 WIB | 8.070 Views. http://www.antaranews.com/ berita/492363/ini-inovasi-budidaya-rumputlaut-di-tambak-ikan-udang

King. Victor T. (2013). Borneo and Beyond: Reflections on Borneo Studies, Anthropology and the Social Sciences. Working Paper Series 3 Institute of Asian Studies, Universiti Brunei Darussalam. Gadong.

Komisi II DPRD Monitoring Pembangunan Multy Years Contract di Kecamatan Samboja. dprdkutaikartanegara.go.id - 13/08/2015 15:01 WITAhttp://www.dprdkutaikartanegara.go.id/ bacawarta.php?id=2157

Kusumawati, R.a , Visser, L.b (2016). Capturing the Elite in Marine Conservation in Northeast Kalimantan (2016) Human Ecology (Russian Federation), 44 (3), pp. 301-310. https://www. scopus.com/inward/record.uri?eid=2-s2.084976331122\&partnerID $=40 \& \mathrm{md} 5=555 \mathrm{a} 071$ efc4c5d21a494fad840bb8df0

Liu, Z.a b , Müller, M.a , Rommel, J.c , Feng, S.b (2016). Community-based agricultural land consolidation and local elites: Survey evidence from China. Journal of Rural Studies, . Article in Press. https://www.scopus.com/inward/ record.uri?eid=2-s2.0-84978870327\&partne $\mathrm{rID}=40 \& \mathrm{md} 5=86 \mathrm{dbf} 6 \mathrm{f} 3 \mathrm{f} 4173 \mathrm{fbe} 7227 \mathrm{fe} 3 \mathrm{cba}$ $\mathrm{cc0b} 4 \mathrm{c}$

Lucas, A. (2016). Elite Capture and Corruption in two Villages in Bengkulu Province, Sumatra. Human Ecology (Russian Federation), 44 (3), pp. 287-300. https://www.scopus.com/inward/ record.uri?eid=2-s2.0-84975733117\&partne $\mathrm{rID}=40 \& \mathrm{md} 5=68 \mathrm{a} 401 \mathrm{f} 62 \mathrm{ef} 8 \mathrm{~b} 4 \mathrm{f} 108395 \mathrm{~b} 0 \mathrm{f0}$ $3 a 9 a 26 d$

Maniokas, K. (2014). Theoretical approach: Europeanization, elites, state capture and 
development [Teorine prieiga: Europeizacija, elitai, valstybes užgrobimas ir vystymasis] (2014) Politologija, 4 (76), pp. 3-39.

Mitchell, Ronald K. Agle, Bradley R. and Wood, Donna J. (1997). Toward a Theory of Stakeholder Identification and Salience: Defining the Principle of Who and What Really Counts Author(s): Source: The Academy of Management Review, Vol. 22, No. 4 (Oct., 1997), pp. 853-886. Published by: Academy of Management. Stable URL: http://www. jstor.org/stable/259247 Accessed: 28-11-2016 02:34 UTC

Nelayan Mengeluh Kawasan Tangkapan Ikan Berkurang. https://www.1news.id/2015/10/ dewan-kukar-tembak-perusahaan-migas/

Nelayan Mulai Susah Mencari Ikan: Diduga Akibat Sawit dan Kebiasaan Nyetrum Ikan. http:// www.korankaltim.com/nelayan-mulai-susahmencari-ikan/.

Nelayan Samboja Minta Waktu dan Solusi http://news. kutaikartanegarakab.go.id $/ ? \mathrm{p}=7523$. Down load 02112016. 12.00 wib.

P.A.M. Van Zwieten, Sidik, A.S., Noryadi Suyatna, I., Abdunnur (2006). Aquatic food production in the coastal zone: Data-based perceptions on the trade-off between mariculture and fisheries production of the Mahakam Delta and estuary, East Kalimantan, Indonesia. Environment and Livelihoods in Tropical Coastal Zones: Managing Agriculture-Fishery-Aquaculture Conflicts . 3 July, Pages 219-236.

Peluso. Nancy Lee (2008). A political ecology of violence and territory in West Kalimantan. Asia Pacific Viewpoint, Vol. 49, No. 1, April. ISSN 1360-7456, pp48-67.

Perairan Kaltim Over Fishing. http://newsbalikpapan. com/perairan-kaltim-fishing.html. 23 October 2014

Platteau, J.-P.a , Somville, V.b , Wahhaj, Z.C. (2014). Elite capture through information distortion: A theoretical essay. (2014) Journal of Development Economics, 106,pp. 250-263.

Platteau, Jean-Philippe and Gaspart, Frédéric (2003). The 'Elite Capture' Problem in Participatory Development. Centre for Research on the Economics of Development (CRED). Faculty of Economics Rempart de la Vierge, 8 B-5000 Namur Belgium

Produksi Perikanan Kaltim Capai 154.439 Ton. Senin, 11 April 2016 16:33 WIB. http:// kaltim.antaranews.com/berita/31700/ produksi-perikanan-kaltim-capai-154439-ton. Download 04112016.

Rakhmat, Saipul, dan Alwi, Hamka (2015). Policy Implementation Of Poverty Reduction In The District Kutai Kartanegara In East Kalimantan Province . International Journal of Scientific and Technology Research. Vol 4, No 01, January. Pp: 116-119.

Ratusan Nelayan Tutup SPBU http://m.jpnn.com// news_comment.php?id=93217. Kamis, $26 \mathrm{Mei}$ $2011,13: 19: 00$

Rigon, A. '(2014). Building local governance: Participation and elite capture in slumupgrading in Kenya (2014) Development and Change, 45 (2), pp. 257-283.

Sabiham, Supiandi (1988). Studies on Peat in the Coastal Plains of Sumatra and Borneo Part I: Physiography and Geomorphology of the Coastal Plains. Southeast Asian Studies, Vol. 26, No.3, December.pp: 308-335.

Sarwono (1989). Effects of the Forest Fire 1982/83 in East Kalimantan on Fishery and Hydrology Investigation of the Steps Needed to Rehabilitate the Areas of East Kalimantan Seriously Affected by Fire. FR-Report No. 8.

Sidik, A. (2008) The Changes of Mangrove Ecosystem in Mahakam Delta, Indonesia: A Complex Social-Environmental Pattern of Linkages in Resources Utilization.

SPE/APPEA International Conference on Health, Safety and Environment in Oil and Gas Exploration and Production 2012: Protecting People and the Environment - Evolving Challenges; Perth, WA; Australia; 11 September 2012 through 13 September 2012; Code 96166

Supriharyono (2000). Coastal and Marine Environment Problems in East Kalimantan Province. Journal of Coastal Development. Vol. 3. No 2. February. PP: 559-565. ISSN: 1410-5217.

Suyatna I, Bratawinata AA, SidikAS, Ruchaemi A (2011) Demersal fishes and their distribution in estuarine waters of Mahakam Delta,East Kalimantan. Biodiversitas 12: 204-210.

Tate, D. Building a Global Driving Program that Delivers Superior Results. (2004) SPE International Conference on Health, Safety and Environment in Oil and Gas Exploration and Production, Calgary, Alberta, Canada, 29-30 March.

Teluk Balikpapan: Demi Kawasan Industri, RTRW 
Singkirkan Keragaman Hayati Mangrove. April 24, 2013 Hendar (Kontributor Kalimantan Timur) http://www.mongabay. co.id/2013/04/24/teluk-balikpapan-demikawasan-industri-rtrw-singkirkan-keragamanhayati-mangrove/

Warren, C. (2016). Introductory Note on Human Ecology Themed Section: Themed Section Title: Revisiting Leadership, Elite Capture and Good Governance in Conservation and Development Programs: Case Studies from Indonesia Human Ecology (Russian Federation), 44 (3), p. 275. https://www. scopus.com/inward/record.uri?eid=2-s2.084973097846\&partnerID $=40 \& \mathrm{md} 5=$ bc9ea03 c959cffb6f5e33bbc2f742051

Warren, C.a , Visser, L.b. (2016). The Local Turn: An
Introductory Essay Revisiting Leadership, Elite Capture and Good Governance in Indonesian Conservation and Development Programs. Human Ecology (Russian Federation), 44 (3), pp. 277-286. Cited 1 time.https://www. scopus.com/inward/record.uri?eid $=2$-s2.0$84973094008 \&$ partnerID $=40 \& \mathrm{md} 5=873 \mathrm{c} 6 \mathrm{cc}$ cdc6c3ff $8 \mathrm{c} 6 \mathrm{f} 70668 \mathrm{c} 238 \mathrm{fb} 45$

Wilson, G. (2006). "Beyond the Technocrat? The Professional Expert in Development Practice". Development and Change 37(3): 501-23.

Yuliani (2012). Trend Tingkat Kesejahteraan Nelayan di Wilayah Pesisir Kabupaten Kutai Kartanegara (Trend of Welfare Fishermen at Coastal Area of Kutai Kartanegara Regency) Marine Fisheries ISSN 2087-4235 Vol. 3, No. 2 , November 2012 Hal: 177-183 